\title{
Investigation of equilibrium, kinetic, thermodynamic and mechanism of Basic Blue 16 adsorption by montmorillonitic clay
}

\author{
Ahmet Günay • Bahri Ersoy • Sedef Dikmen • \\ Atilla Evcin
}

Received: 9 October 2012/Accepted: 5 February 2013/Published online: 20 February 2013

(C) Springer Science+Business Media New York 2013

\begin{abstract}
The adsorption of a cationic dye, Basic Blue 16 (BB16), by montmorillonitic clay was studied in detail. Changes in the molecular structure during adsorption were analyzed by FTIR spectroscopy. BB16 adsorption onto the clay mainly results from hydrogen bonding between $\mathrm{OH}$ and $\mathrm{NH}_{2}$ groups of dye molecules and $\mathrm{OH}$ groups of clay and electrostatic interaction between the negatively charged clay surface and cationic dye. The montmorillonitic clay dose had an inverse effect on the adsorption performance, while the highest dye removal was $305 \mathrm{mg} / \mathrm{g}$ at $\mathrm{pH}$ 3.6. An increase in temperature and dye concentration positively enhanced the adsorption capacity of the montmorillonitic clay. Temperature had no effect on the adsorption at a dye concentration less than $500 \mathrm{mg} / \mathrm{L}$, while dye adsorption was positively enhanced at elevated dye concentrations. Three-parameter equations provided higher better fitting than two-parameter equations while the Freundlich model had the highest correlation coefficient
\end{abstract}

\footnotetext{
A. Günay

Environmental Protection Department, Istanbul Metropolitan

Municipality, 34169 Istanbul, Turkey

B. Ersoy

Faculty of Engineering, Mining Engineering Department,

Afyon Kocatepe University, 03200 Afyonkarahisar, Turkey

S. Dikmen $(\bowtie)$

Faculty of Science, Department of Physics, Anadolu University, 26470 Eskisehir, Turkey

e-mail: sdikmen@anadolu.edu.tr
}

\section{A. Evcin}

Faculty of Engineering, Materials Science \& Engineering Department, Afyon Kocatepe University, 03200 Afyonkarahisar, Turkey and the lowest error values with experimental data. The BB16 adsorption was well followed by pseudo-second order model and the rate of adsorption process was controlled by surface and intraparticle diffusion. Thermodynamic evaluations revealed that the adsorption process was spontaneous and endothermic, while the randomness increased during adsorption. Experimental results indicate that montmorillonitic clay from Eskisehir is a promising adsorbent for the removal of cationic dye molecules from aqueous solutions.

Keywords Montmorillonitic clay - Basic dye · Isotherm · Kinetic Thermodynamic parameters

\section{List of symbols}

$a_{\mathrm{K}} \quad$ Khan model constant (dimensionless)

$a_{\mathrm{L}} \quad$ Langmuir isotherm constant related to energy of adsorption $(\mathrm{L} / \mathrm{g})$

$a_{\mathrm{RP}} \quad$ Redlich-Peterson isotherm constant $(\mathrm{L} / \mathrm{mg})$

$a_{\mathrm{s}} \quad$ Sips constant related to energy of adsorption $(\mathrm{mg} / \mathrm{L})^{-1 / n}$

$b \quad$ Temkin isotherm energy constant $(\mathrm{J} / \mathrm{mol})$

$b_{\mathrm{K}} \quad$ Khan model constant (dimensionless)

$C \quad$ Constant of Weber-Morris kinetic model (mg/g)

$C_{\mathrm{e}} \quad$ Adsorbate equilibrium liquid phase concentration (mg/L)

$C_{\mathrm{o}} \quad$ Initial adsorbate liquid phase concentration (mg/L)

$D_{\mathrm{i}} \quad$ Diffusivity of Vermeulen $\left(\mathrm{m}^{2} / \mathrm{s}\right)$

$d_{\mathrm{p}} \quad$ Diameter of adsorbent (m)

E Characteristic adsorption energy of DubininRadushkevich model (kJ/mol)

$k_{\mathrm{pt}} \quad$ Constant of Weber-Morris kinetic model $\left(\mathrm{mg} /\left(\mathrm{g} \min ^{1 / 2}\right)\right)$ 
$k_{1} \quad$ The rate constant of pseudo-first order model (L/min)

$k_{2} \quad$ The rate constant of pseudo-second order model $(\mathrm{kg} / \mathrm{g}$ min)

$K_{\mathrm{F}} \quad$ Freundlich model constant $(\mathrm{L} / \mathrm{g})$

$K_{\mathrm{RP}} \quad$ Redlich-Peterson isotherm model constant $(\mathrm{L} / \mathrm{g})$

$K_{\mathrm{Te}} \quad$ Equilibrium binding constant (L/g)

$K_{\text {To }} \quad$ Toth model constant (dimensionless)

$m \quad$ Mass of adsorbent $(\mathrm{g})$

$m \quad$ Number of parameters of the isotherm equation

$n \quad$ Heterogeneity factor of Freundlich model (dimensionless)

$p \quad$ Number of data points in Hybrid function (dimensionless)

$q_{\mathrm{e}} \quad$ Adsorbate solid phase concentration at equilibrium $(\mathrm{mg} / \mathrm{g})$

$q_{\mathrm{k}} \quad$ Khan model constant (dimensionless)

$q_{\mathrm{m}} \quad$ Maximum adsorption capacity of Langmuir model $(\mathrm{mg} / \mathrm{g})$

$q_{\mathrm{s}} \quad$ Monolayer adsorption capacity (mg/g)

$q_{\mathrm{t}} \quad$ Adsorbate solid phase concentration at time $\mathrm{t}$ $(\mathrm{mg} / \mathrm{g})$

$R \quad$ Universal gas constant $(8.314 \mathrm{~J} / \mathrm{mol} \mathrm{K})$

$R^{2} \quad$ Correlation coefficient

sp Sips isotherm exponent

tn Toth isotherm exponent $(0<n \leq 1)$

$T \quad$ Solution temperature (K)

$V \quad$ Volume of solution (mL)

$\beta \quad$ Redlich-Peterson isotherm exponent $(0<\beta<1)$

HYBRID Hybrid fractional error function

$N \quad$ Number of data points in hybrid error function

$P \quad$ Number of parameter in hybrid error function

$K_{\mathrm{D}} \quad$ Distribution coefficient of the dye

$\Delta G^{\circ} \quad$ Gibbs free energy change $(\mathrm{kJ} / \mathrm{mol})$

$\Delta H^{\circ} \quad$ Enthalpy change $(\mathrm{kJ} / \mathrm{mol})$

$\Delta S^{\circ} \quad$ Entropy change $(\mathrm{kJ} / \mathrm{mol})$

\section{Introduction}

Dyes are widely used to color their many industrial products, such as textile, paper, printing, food and so on. Dyes can be classified based on their chemical properties as acid, basic, direct, mordant, reactive, disperse, azo, and sulfur dyes (Demirbas 2009). Basic dyes are also commonly known as cationic dyes due to the release of coloured cations into aqueous solution (Gupta 2009). Basic dyes are widely applied in acrylic, wool, nylon and silk dyeing and also used as a biological stain in biomedical laboratories (Inbaraj et al. 2006; Salleh et al. 2011). The discharge of basic dyes without proper treatment is a problematic issue due to the harmful effects on humans and other living organisms (Lin et al. 2010; Chen and Zhao 2009). Therefore, removal of basic dyes from effluents is a major challenge prior to discharge into communal biological treatment plants or destination aquatic bodies.

Various methods have been proposed for wastewater treatment of basic dyes, such as biological treatment (Sarioglu et al. 2007) membrane separation (Akbari and Aptel 2002), chemical oxidation (Bouafia-Chergui et al. 2010) and combined biological and chemical systems. However, these treatment methods have suffered limitations due to the resistance of chemical structures of basic dyes to breakdown by chemical, physical and biological treatments (Turabik 2008). Various low-cost adsorbents have been used for the treatment of basic dyes, such as activated carbon (Karagozoglu et al. 2007; Juang et al. 2001), agricultural waste (Salleh et al. 2011), spent tea leaves (Hameed 2009), chitosan (Crini and Badot 2008), activated sludge (Gulnaz et al. 2004), fly ash (Gupta et al. 2000), sand (Bukallah et al. 2007), bentonite (Eren and Afsin 2008) and zeolite (Meshko et al. 2001).

In recent years, natural clay minerals have received considerable recognition for their adsorption applications due to low-cost abundant resources, and higher specific surface areas (Ozcan et al. 2005). Clays are hydrous aluminasilicate minerals containing mainly alkali metal (e.g. $\mathrm{Na}^{+}, \mathrm{K}^{+}$) and alkaline-earth-metal (e.g. $\mathrm{Ca}^{+2}, \mathrm{Mg}^{+2}$ ) in the framework. Based on crystalline structure, clays are classified as one, two or three dimensional lattice. Montmorillonite is the most common clay mineral, which is a 2:1 type aluminasilicate. The inner layer is composed of an octahedral sheet situated between two $\mathrm{SiO}_{4}$ tetrahedral sheets. The substitutions within the lattice structure of $\mathrm{Mg}^{2+}$ in place of $\mathrm{Al}^{3+}$ in the octahedral sheet and, to substitutions of $\mathrm{Al}^{+3}$ in place of $\mathrm{Si}^{4+}$ in the tetrahedral sheet result in a negative charge on the montmorillonite surface (Ozcan and Ozcan 2004; Bergaya et al. 2006). Montmorillonite has been successfully used for the removal of metals (Chavez et al. 2010), pharmaceuticals (Li et al. 2011), dyes (Ely et al. 2009; Almeida et al. 2009; Ozcan and Ozcan 2004) and surfactants (Lin et al. 2009) and phosphate (Tian et al. 2009). Liu and Zhang (2007) also reported a comprehensive review on the adsorption properties of different montmorillonite types for various pollutants. Hajjaji and Alami (2009) investigated methylene blue adsorption by three different montmorillonites and reported that Na-montmorillonite had a higher adsorption capacity than raw montmorillonite and $\mathrm{NH}_{4}{ }^{+}$montmorillonite. Wang et al. (2004) compared the adsorption capacities of two cationic dyes onto raw montmorillonitic clay and Ti-montmorillonite and found that montmorillonitic clay had a better performance due to the easy displacement of $\mathrm{Ca}^{2+}$ by ion exchange. Researchers have recently reported successful applications of montmorillonitic clay for the removal of cationic dyes from an aqueous solution 
(Roulia and Vassiliadis 2005; Wang et al. 2004; Iyim and Güclü 2009). However, as we know, there has been no study to date for the adsorption of Basic Blue 16 (BB16) by any adsorbent. In this study, isotherm, kinetic and thermodynamic evaluation of BB16 adsorption by montmorillonitic clay was studied and its applicability of various model equations with experimental data was tested.

\section{Materials and methods}

\subsection{Materials}

A clay sample was supplied by Dolsan Company from Eskisehir, Turkey. The surface charge of the clay sample was measured by a zeta meter (Malvern Zetasizer Nano ZS) as $-29 \mathrm{mV}$ at $\mathrm{pH} 6.8$ in pure water. The BB16 was obtained from Sigma-Aldrich. The molecular structure of the BB16 is illustrated in Fig. 1. The chemical formula and chemical abstract service (CAS) registry number are $\mathrm{C}_{30} \mathrm{H}_{24} \mathrm{~N}_{5} \mathrm{O} \cdot \mathrm{Cl}$ and 4569-88-4 respectively, while the dye content is $70 \%$.

\subsection{Adsorption experiments}

All adsorption experiments were conducted in batch mode at $140 \mathrm{rpm}$. A stock dye solution was prepared as $2000 \mathrm{mg} / \mathrm{L}$ by stirring for 2 days at room temperature to completely dissolve the dye molecules. Natural $\mathrm{pH}$ of synthetic dye solution was 3.6. Desired dye concentrations were prepared by the dilution of stock solution with distilled water.

The adsorbent dose was optimized in the range of 0.75-10 g/L at natural $\mathrm{pH}(\mathrm{pH} 3.6)$. The effect of solution $\mathrm{pH}$ on the adsorption was studied between 2 and 10 at $2 \mathrm{~g} / \mathrm{L}$ of the adsorbent dose. The solution $\mathrm{pH}$ was adjusted to the desired level using $0.1 \mathrm{M} \mathrm{NaOH}$ and $\mathrm{HCl}$. These experiments were conducted at room temperature $\left(25 \pm 2{ }^{\circ} \mathrm{C}\right)$ with an initial dye concentration of $750 \mathrm{mg} / \mathrm{L}$, while the stirring duration was $24 \mathrm{~h}$. Isotherm and kinetic experiments were performed at three temperatures $\left(15,25\right.$ and $\left.35^{\circ} \mathrm{C}\right)$ and three dye concentrations $(250,500$ and $1000 \mathrm{mg} / \mathrm{L})$.

\subsection{Analyses}

Minerological and chemical analyses of clay sample were conducted by XRD (Rigaku RINT 2200), and XRF (Bruker<smiles>Cc1cc2nc3cc(C)c(/N=N/c4c(O)ccc5ccccc45)cc3[n+](-c3ccccc3)c2cc1N</smiles>

Fig. 1 Chemical structure of BB16
Tiger S8). BET surface area was calculated from $\mathrm{N}_{2}$ adsorption isotherm $\left(P / P_{\mathrm{o}}<0.3\right)$ with a surface area analyzer (Quantachrome, Nova 2200). Particle size distribution of the sample was determined using a Malvern Mastersizer 2000. Fourier transform infrared (FTIR) technique was used to analysis the chemical surface groups of the adsorbent and dye. The FTIR analysis was performed using a spectrophotometer (Perkin-Elmer, BX-2) equipped with a $\mathrm{KBr}$ beam splitter. The spectra were recorded in the region of 4,000-400 $\mathrm{cm}^{-1}$ with a resolution of $4 \mathrm{~cm}^{-1}$.

The dye concentration in the aqueous solution was measured using a UV-visible spectrophotometer (Jenway). After the experiments, solid and liquid phases were centrifuged using a temperature-controlled centrifuge (Eppendrof, 5702RH) at 10,000 rpm for $2 \mathrm{~min}$ and the clear solution was measured at $589 \mathrm{~nm}$.

As a function of the dye concentration, the zeta potential of montmorillonitic clay sample was measured by using zetameter at 25 and $45^{\circ} \mathrm{C}$. The suspensions were kept still for $10 \mathrm{~min}$ to let larger particles settle at the same temperature. A sample of $0.1 \mathrm{~g}$ in $50 \mathrm{~mL}$ of dye solution which has a certain concentration was shaken for $24 \mathrm{~h}$. Approximately $10 \mathrm{~mL}$ of clear supernatant was removed from the adsorption test vial and placed in the electrophoretic cell. An adequate amount of solid sample was taken from the clay bad in the vial and introduced to cell. Afterwards, zeta potential of the clay particles was measured.

\subsection{Isotherm and kinetic modeling}

The amount of dye adsorbed on the adsorbent $(\mathrm{mg} / \mathrm{g}$ ) was calculated by dividing the difference between the initial dye concentrations $(\mathrm{mg} / \mathrm{L})$ and that remaining after adsorption $(\mathrm{mg} / \mathrm{L})$ to the amount of adsorbent $(\mathrm{g})$.

In order to estimate the validity of isotherm models with experimental data, two-parameter equations namely, Freundlich (1906), Langmuir (1916), Dubinin (1960), Temkin (Aharoni and Sparks 1991) and three-parameter models, namely Redlich and Peterson (1959), Sips (1948), Toth (1971) and Khan et al. (1996) were tested. The equations of these isotherm models are given in Table 1.

To analyze the kinetics of BB16 adsorption by clay mineral, the experimental data at different temperatures and concentrations were fitted with four models, namely pseudo-first-order (Langergen and Svenska 1898), pseudosecond-order (Ho and Mckay 1999), Weber-Morris (Rauf et al. 1996), and Vermeulen (1953) (Table 2).

Nonlinear regression analysis was applied to estimate the isotherm and kinetic model parameters. Nonlinear regression was performed using trial and error method with the help of solver add-in functions of Microsoft Excel software. In trial error procedure, isotherm and kinetic parameters were estimated by maximizing the coefficient 
Table 1 Two and three-parameter equations for isotherm modeling

\begin{tabular}{|c|c|c|}
\hline & Formula & Parameters \\
\hline \multicolumn{3}{|l|}{ Two-parameter models } \\
\hline Freundlich & $q_{\mathrm{e}}=K_{\mathrm{F}} C_{\mathrm{e}}^{1 / n}$ & $K_{\mathrm{F}}, n$ \\
\hline Langmuir & $q_{\mathrm{e}}=\frac{q_{\mathrm{m}} a_{\mathrm{L}} C_{\mathrm{e}}}{1+a_{\mathrm{L}} C_{\mathrm{e}}}$ & $q_{\mathrm{m}}, a_{\mathrm{L}}$ \\
\hline Dubinin-Radushkevich & $q_{\mathrm{e}}=q_{\mathrm{m}} \exp \left(\frac{\left.R T \ln \left(1+1 / C_{\mathrm{e}}\right)\right)^{2}}{-2 E^{2}}\right)$ & $q_{\mathrm{s}}, E$ \\
\hline Temkin & $q_{\mathrm{e}}=\left(\frac{R T}{b}\right) \ln \left(K_{\mathrm{Te}} C_{\mathrm{e}}\right)$ & $b, K_{\mathrm{Te}}$ \\
\hline \multicolumn{3}{|l|}{ Three-parameter models } \\
\hline Redlich-Peterson & $q_{\mathrm{e}}=\frac{K_{\mathrm{RP}} C_{\mathrm{e}}}{1+a_{\mathrm{RP}} C_{\mathrm{e}}^{\beta}}$ & $K_{\mathrm{R} P}, a_{\mathrm{R} P}$, \\
\hline Sips & $q_{\mathrm{e}}=\frac{q_{\mathrm{s}} a_{\mathrm{S}} \mathrm{C}_{\mathrm{e}}^{1 / \mathrm{sp}}}{1+a_{\mathrm{s}} \mathrm{C}_{\mathrm{e}}^{1 / \mathrm{sp}}}$ & $q_{\mathrm{s}}, a_{\mathrm{S}}, \mathrm{sp}$ \\
\hline Toth & $q_{\mathrm{e}}=\frac{q_{\mathrm{m}} C_{\mathrm{e}}}{\left(K_{\mathrm{To}}+C_{\mathrm{e}}^{\mathrm{tn}}\right)^{1 / \mathrm{m}}}$ & $q_{\mathrm{m}}, K_{\mathrm{To}}$, tn \\
\hline Khan & $q_{\mathrm{e}}=\frac{q_{\mathrm{k}} b_{\mathrm{K}} C_{\mathrm{e}}}{\left(1+b_{\mathrm{K}} C_{\mathrm{e}}\right)^{a_{\mathrm{K}}}}$ & $q_{\mathrm{m}}, b_{\mathrm{K}}, a_{\mathrm{K}}$ \\
\hline
\end{tabular}

Table 2 Equations used for kinetic modeling

\begin{tabular}{lll}
\hline Kinetic model & Formula & Parameters \\
\hline Pseudo-first-order & $q_{\mathrm{t}}=q_{\mathrm{e}}-\frac{q_{\mathrm{e}}}{\mathrm{e}^{\left(k_{1} t\right)}}$ & $k_{1}, q_{\mathrm{e}}$ \\
Pseudo-second-order & $q_{\mathrm{t}}=\frac{k_{2} q_{\mathrm{e}}^{2}}{1+k_{2} q_{\mathrm{e}} t}$ & $k_{2}, q_{\mathrm{e}}$ \\
Weber-Morris & $q_{\mathrm{t}}=k_{\mathrm{p}} t^{0.5}+C$ & $k_{\mathrm{p}}, C$ \\
Vermeulen & $q_{\mathrm{t}}=q_{\mathrm{e}}\left[1-\exp \left(-\frac{4 \pi^{2} D_{\mathrm{i}} \mathrm{t}}{d_{\mathrm{p}}^{2}}\right)\right]^{1 / 2}$ & $q_{\mathrm{e}}, D_{\mathrm{i}}, d_{\mathrm{p}}$ \\
\hline
\end{tabular}

of determination $\left(R^{2}\right)$ and minimizing the value of Hybrid error function. Both the coefficient of determination and Hybrid error function has been widely employed to measure the fitting degree of model to adsorption data (Gimbert et al. 2008; Foo and Hameed 2010). The coefficient determination was calculated as (Ho 2006):

$R^{2}=\frac{\sum\left(q_{\mathrm{mod}}-q_{\mathrm{exp}}\right)^{2}}{\sum\left(q_{\mathrm{mod}}-q_{a \exp }\right)^{2}+\left(q_{\mathrm{mod}}-q_{\exp }\right)^{2}}$

where $q_{\exp }(\mathrm{mg} / \mathrm{g})$ is equilibrium value obtained from the experiment, $q_{\text {mod }}$ is calculated by model $q_{\text {aexp }}$ and is the average of $q_{\text {exp }}$.

The hybrid error function (HYBRID) was developed by Porter et al. (1999) and can be calculated as follows:

HYBRID $=\frac{100}{N-P} \sum_{i=1}^{N}\left[\frac{\left(q_{\mathrm{e}, \exp }-q_{\mathrm{e}, \mathrm{cal}}\right)^{2}}{q_{\mathrm{e}, \mathrm{exp}}}\right]_{i}$

where $N$ is the number of data points and $P$ is the number of parameters.

\subsection{Thermodynamic evaluation}

The thermodynamic state functions (free energy, enthalpy and entropy) are important indicators when estimating the mechanism of adsorption process. The standard Gibbs energy $\left(\Delta G^{\circ}\right)$ was estimated by applying the thermodynamic equation as follows (Ozdemir et al. 2011):

$\Delta G^{o}=-R T \ln K_{\mathrm{D}}$

$\Delta H^{\circ}$ and $\Delta S^{\circ}$ were estimated using the Van't Hoff equation (Mane and Datta 2011).

$\ln K_{\mathrm{D}}=\frac{\Delta S^{o}}{R}-\frac{\Delta H^{o}}{R T}$

where, $R$ is the gas constant $(8.314 \mathrm{~J} / \mathrm{molK}), T$ solution temperature $(\mathrm{K})$ and $K_{\mathrm{D}}$ is the distribution coefficient of the dye between the adsorbed layer and the solution.

\section{Results and discussion}

\subsection{Characterization of sample}

The natural clay sample used in this work was provided from DOLSAN Inc., which belongs to Eskişehir region of Turkey. The mineralogical, chemical and physical properties of the clay sample are also reported and given in Table 3. Its mineral content (in wt $\%$ ) is montmorillonite $(52.35 \%)$, cristobalite $(27.51 \%)$, calcite $(9.10 \%)$, kaolinite $(8.08 \%)$ and quartz $(3.95 \%)$. Due to its high montmorillonite content, the clay mineral is referred to as montmorillonitic clay. The main chemical constituents of the clay are silica $(60.90 \%)$, alumina $(11.67 \%), \mathrm{CaO}$ $(4.33 \%)$ and $\mathrm{MgO}(3.30 \%)$ while the loss of ignition was $18.0 \%$.

\subsection{FTIR spectroscopy}

Figure 2a-c shows the FTIR spectra of montmorillonitic clay, BB16 and BB16 adsorbed montmorillonitic clay. There is a group of absorption peaks observed at 3434 and $3627 \mathrm{~cm}^{-1}$, which is assigned to the $\mathrm{H}-\mathrm{O}-\mathrm{H}$ stretching vibration bands of adsorbed water molecules weakly hydrogen bonded to the $\mathrm{Si}-\mathrm{O}$ surface in the montmorillonitic clay (Fig. 2a), and the band at $1625 \mathrm{~cm}^{-1}$ also corresponding to the $\mathrm{H}-\mathrm{O}-\mathrm{H}$ bending vibrations. A pair of bands is observed at 1090 and $1020 \mathrm{~cm}^{-1}$ as a result of the $\mathrm{Si}-\mathrm{O}$ stretching vibrations. On the other hand, the $1020 \mathrm{~cm}^{-1}$ band is assigned to the stretching of $\mathrm{Si}-\mathrm{O}$ in the $\mathrm{Si}-\mathrm{O}-\mathrm{Si}$ groups of the tetrahedral layer. The band at 915 is due to $\mathrm{Al}-\mathrm{Al}-\mathrm{OH}$ bending vibrations, indicating the initial layered silicate structure. The $\mathrm{Si}-\mathrm{O}$ stretching of $\mathrm{SiO}_{2}$ impurity appears at $793 \mathrm{~cm}^{-1}$ and the $\mathrm{Si}-\mathrm{O}$ out of plane vibrations $\left(615 \mathrm{~cm}^{-1}\right)$ could be attributed to cristobalite. After adsorption, the disappearance of these bands depends on the loading dye, confirming the intercalation of dye molecules between the silica layers. Finally, a pair of bands is observed at 520 and $467 \mathrm{~cm}^{-1}$, which 
are due to $\mathrm{Si}-\mathrm{O}-\mathrm{Al}$ (where $\mathrm{Al}$ is an octahedral cation) and $\mathrm{Si}-$ O-Si bending vibrations, respectively (van der Marel and Beutelspacher 1976; Gok et al. 2008; Ghorbel-Abid et al. 2009; Sakizci et al. 2010). This result is in accord with the XRD

Table 3 Properties of the clay sample

\begin{tabular}{|c|c|c|}
\hline Chemical content & Unit & Value \\
\hline $\mathrm{SiO}_{2}$ & $\%$ & 60.90 \\
\hline $\mathrm{Al}_{2} \mathrm{O}_{3}$ & $\%$ & 11.67 \\
\hline $\mathrm{CaO}$ & $\%$ & 4.33 \\
\hline $\mathrm{MgO}$ & $\%$ & 3.30 \\
\hline $\mathrm{Fe}_{2} \mathrm{O}_{3}$ & $\%$ & 0.79 \\
\hline $\mathrm{K}_{2} \mathrm{O}$ & $\%$ & 0.79 \\
\hline $\mathrm{TiO}_{2}$ & $\%$ & 0.07 \\
\hline $\mathrm{MnO}$ & $\%$ & 0.05 \\
\hline Others & $\%$ & 0.10 \\
\hline Loss of ignition & $\%$ & 18.0 \\
\hline \multicolumn{3}{|l|}{ Mineralogical content } \\
\hline Montmorillonite & $\%$ & 52.35 \\
\hline Cristobalite & $\%$ & 27.51 \\
\hline Calcite & $\%$ & 9.10 \\
\hline Kaolinite & $\%$ & 8.08 \\
\hline Quartz & $\%$ & 3.95 \\
\hline \multicolumn{3}{|l|}{ Physical properties } \\
\hline Density & $\mathrm{g} / \mathrm{cm}^{3}$ & 2.33 \\
\hline Spesific surface area & $\mathrm{m}^{2} / \mathrm{g}$ & 74.0 \\
\hline \multicolumn{3}{|l|}{ Particle size distribution } \\
\hline D90 & $\mu \mathrm{m}$ & 30.71 \\
\hline D50 (average) & $\mu \mathrm{m}$ & 10.08 \\
\hline D10 & $\mu \mathrm{m}$ & 2.81 \\
\hline Pore size & $\mathrm{nm}$ & 5-30 (average 14) \\
\hline Porosity & Vol.\% & 24.50 \\
\hline
\end{tabular}

analysis that montmorillonitic clay contains of quartz and cristobalite. As shown in the FTIR spectrum of the dye BB16 (Fig. 2b), the band at $3570 \mathrm{~cm}^{-1}$ was due to the stretching vibration of $\mathrm{O}-\mathrm{H}$ bond in hydroxyl groups. For the chemical structure of BB16, it can be seen that two N-H stretching vibrations for the primary amines ( $\mathrm{R}-\mathrm{NH}_{2}$ functional groups) located at 3440 and $3350 \mathrm{~cm}^{-1}$, and their bending vibrations located around $1600 \mathrm{~cm}^{-1}$. The bands related to $-\mathrm{N}=\mathrm{N}-$ and $\mathrm{C}-\mathrm{O}$ stretching vibrations in the dye molecule are located at 1510 and $1240 \mathrm{~cm}^{-1}$, respectively. In Fig. 2c, FTIR spectrum of montmorillonitic clay adsorbed BB16 is given. Before adsorption, the band at $3627 \mathrm{~cm}^{-1}$, which resulted from the $\mathrm{O}_{-}$ $\mathrm{H}$ deformation of water, was observed for montmorillonitic clay, but this peak was not observed montmorillonitic clay adsorbed BB16. This finding may be acceptable evidence for the interactions between clay and dye molecules. On the other hand, the broad band in the $3500-3300 \mathrm{~cm}^{-1}$, as well as two other bands at 1600 and $1620 \mathrm{~cm}^{-1}$, which are probably due to overlapping of the bands by adsorbed water and adsorbed dye, could appear. The interactions could be hydrogen bonding between the $\mathrm{OH}$ and $\mathrm{NH}_{2}$ groups as well as the $\mathrm{H}_{2}$ bonds involving the positively charged $\mathrm{N}$ atoms of the dye molecule. The FTIR results indicated that there is an interaction between the cationic dye molecules and silica layers.

\subsection{Zeta potential}

Figure 3 shows the variation in zeta potential of clay versus concentration BB16 at temperature of 25 and $45{ }^{\circ} \mathrm{C}$. Cationic dye molecules adsorb on the negatively charged clay surface (preferably onto layer surface) via electrostatic interactions hence zeta potential of clay shifted from negative to positive. Identical observation has been resulted in previous studies on cationic substance adsorption onto different adsorbents such as clays (Sevim et al. 2011) and
Fig. 2 FTIR analysis of montmorillonitic clay, BB16 and BB16 adsorbed montmorillonitic clay

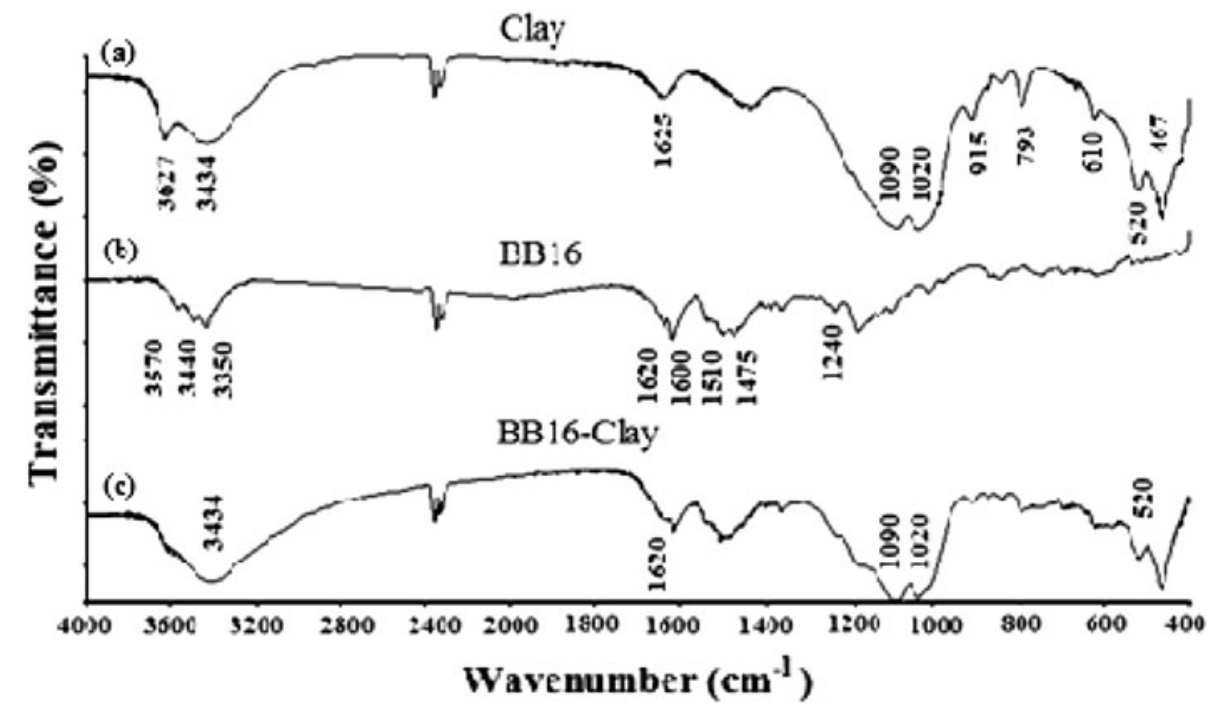


zeolites (Ersoy and Celik 2003). The alteration of surface charge of clay in a very narrow range of concentration suggested that the electrostatic interactions were effective in BB16 adsorption. In addition to electrostatic interaction, ion exchange mechanism between the cationic dye and metal ions present interlayer of the clay is also possible.

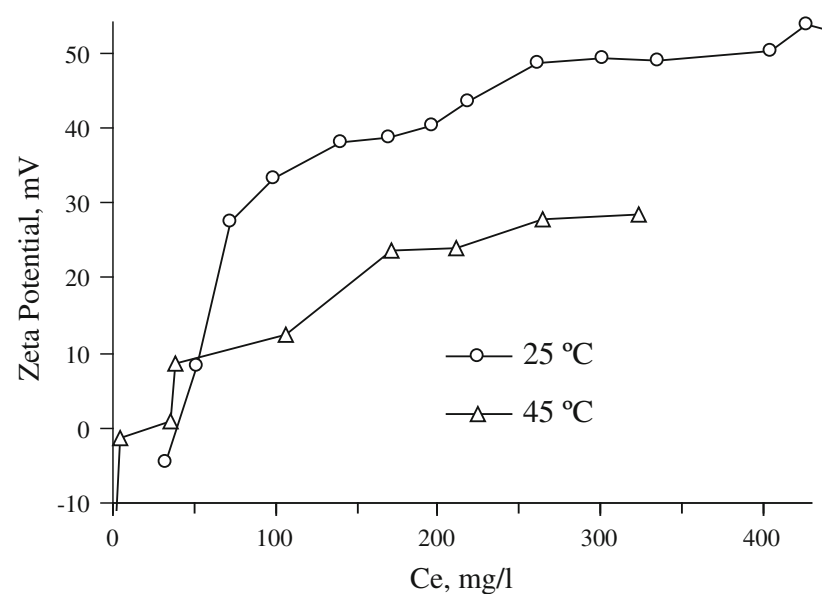

Fig. 3 Variation of zeta potential of montmorillonitic clay as a function of BB16 concentration at 25 and $45^{\circ} \mathrm{C}$, and at natural $\mathrm{pH}$ $(\mathrm{pH} 3.6)$ of the dye solution
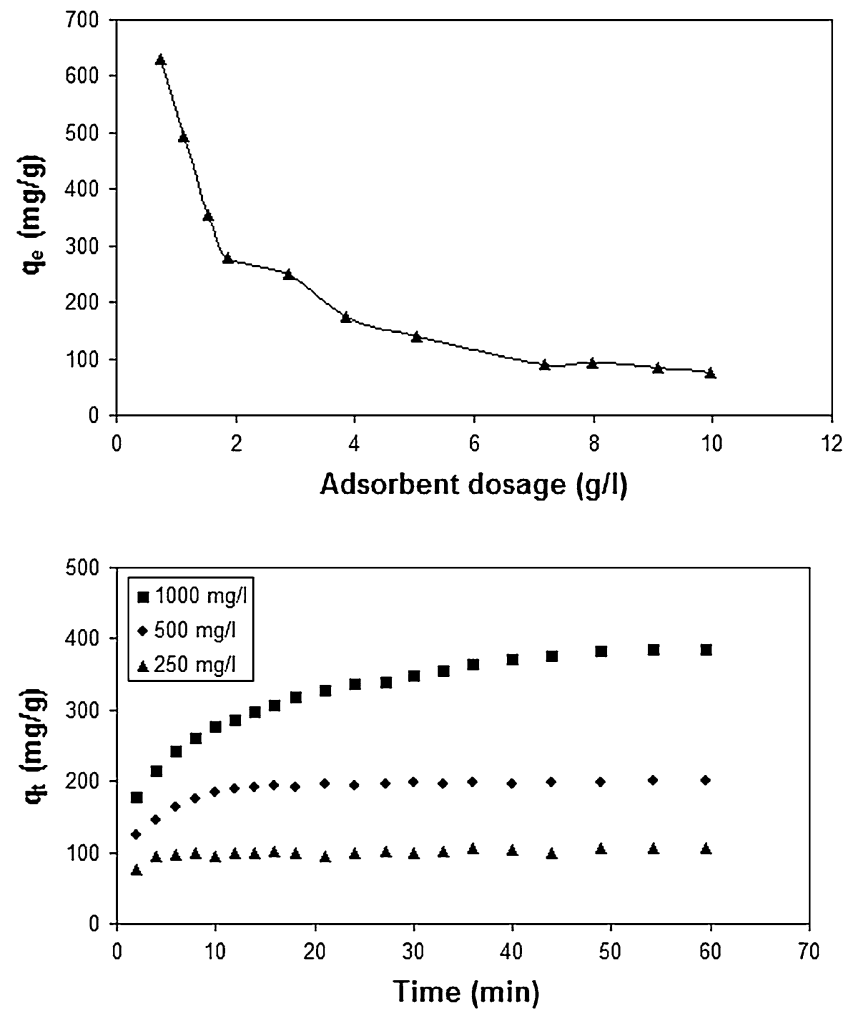

\subsection{Effect of physicochemical parameters}

The effects of adsorbent dose, initial $\mathrm{pH}$, dye concentrations and temperature on BB16 adsorption by montmorillonitic clay are shown in Fig. 4. In all cases, the adsorption rates of the dye were very fast at the initial stages while it slowed gradually as the equilibrium was approached. This could be related to the reduction of available active sites on montmorillonitic clay. There was an inverse relationship between BB16 removal and the adsorbent dose. The amount of dye adsorbed onto montmorillonitic clay decreased from 631.0 to $75.1 \mathrm{mg} / \mathrm{g}$ with an increase in of adsorbent dose from 0.75 to $10 \mathrm{~g} / \mathrm{L}$. The adsorption capacity of the adsorbent was $265 \mathrm{mg} / \mathrm{g}$ at $\mathrm{pH} 2$ and it sharply increased to $305 \mathrm{mg} / \mathrm{g}$ at $\mathrm{pH}$ 3.6. A further increase in $\mathrm{pH}$ resulted in a negative effect on BB16 adsorption. The amount of dye adsorbed decreased to $286 \mathrm{mg} / \mathrm{g}$ at $\mathrm{pH} 5$ and to $239 \mathrm{mg} / \mathrm{g}$ at $\mathrm{pH} 11$. Similarly, Gurses et al. (2006) obtained the maximum basic dye removal on clay at natural $\mathrm{pH}$ and they explain it due to the changes in swelling properties and surface chemistry of clay with $\mathrm{pH}$. Subsequent experiments were performed without $\mathrm{pH}$ adjustment.

The initial dye concentration affected both the adsorption capacity and the equilibrium time. The adsorption process quickly reached equilibrium in low dye concentrations but, the equilibrium time was longer at higher concentrations.
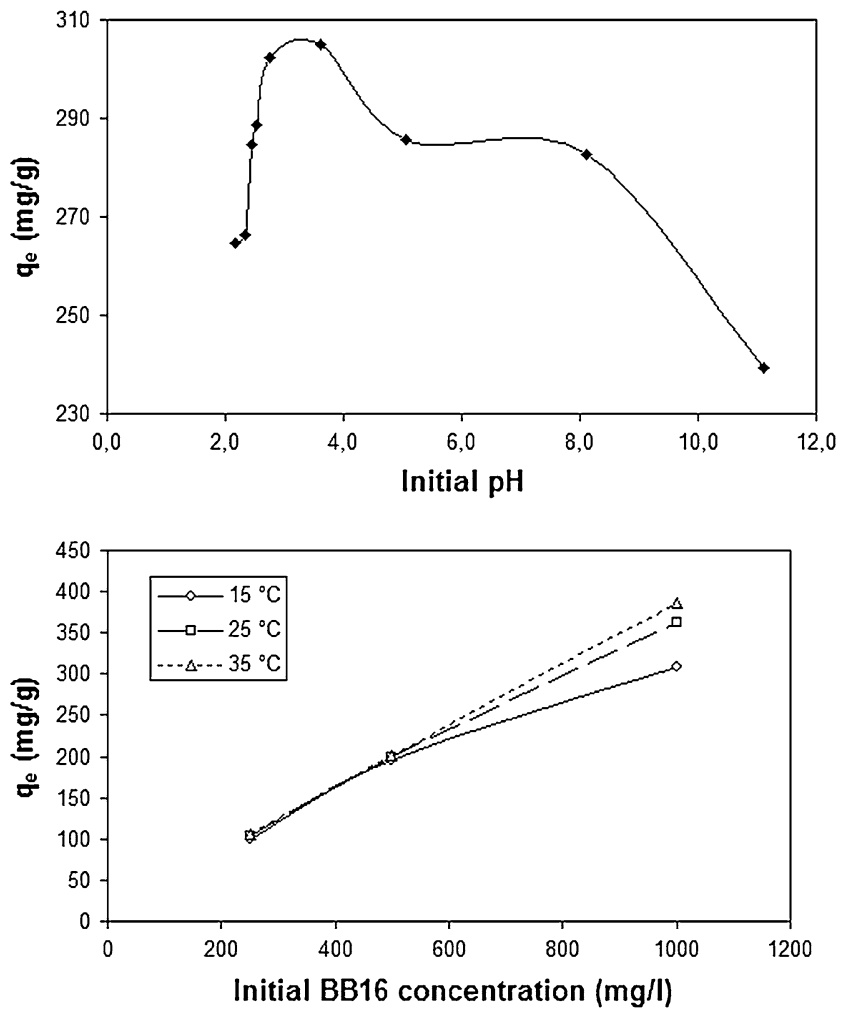

Fig. 4 Effect of parameters on BB16 adsorption by montmorillonitic clay 
Additionally, the initial BB16 concentration enhanced adsorption capacity of montmorillonitic clay. This enhancement could be associated with an increase in gradient between dye solution and adsorbent. A higher gradient promotes the driving force for the transfer of dye molecules from solution to the adsorbent pore surfaces. Similar to dye concentration, temperature positively affected BB16 removal. At dye concentrations less than $500 \mathrm{mg} / \mathrm{L}$, adsorption capacities were close at all temperatures, but temperature has profound effect at higher dye concentrations (Fig. 4). This may be attributed to increased penetration of dye molecules inside micropores of adsorbent at higher temperatures. Similar the relationship between dye concentration and temperature was reported by other researchers (Al-Degs et al. 2008).
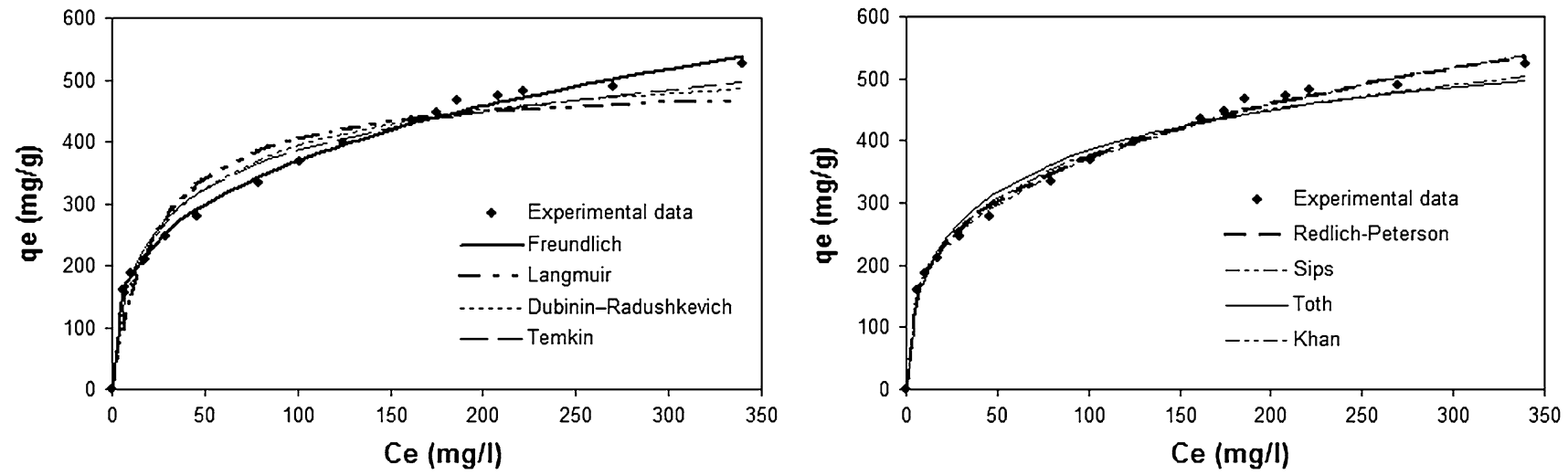

Fig. 5 Comparison of two and three-parameter isotherm models with experimental data $\left(T 25^{\circ} \mathrm{C}\right)$

Table 4 Isotherm parameters for BB16 adsorption by montmorillonitic clay

\begin{tabular}{|c|c|c|c|c|c|c|c|}
\hline & Two-pa & nodel & & & Three-p & model & \\
\hline & $15^{\circ} \mathrm{C}$ & $25^{\circ} \mathrm{C}$ & $35^{\circ} \mathrm{C}$ & & $15^{\circ} \mathrm{C}$ & $25^{\circ} \mathrm{C}$ & $35^{\circ} \mathrm{C}$ \\
\hline Freundlich & & & & Redlich-Peterso & & & \\
\hline$K_{\mathrm{F}}(\mathrm{L} / \mathrm{g})$ & 47.04 & 88.99 & 148.66 & $K_{\mathrm{R}}(\mathrm{L} / \mathrm{g})$ & 247.72 & 211.47 & 130.69 \\
\hline $1 / n$ & 0.413 & 0.309 & 0.225 & $a_{\mathrm{R}}(\mathrm{L} / \mathrm{mg})^{1 / \beta}$ & 4.94 & 2.10 & 0.71 \\
\hline$R^{2}$ & 0.999 & 0.993 & 0.985 & $\beta$ & 0.596 & 0.711 & 0.811 \\
\hline HYBRID & 155.0 & 30.0 & 134.7 & $R^{2}$ & 0.985 & 0.992 & 0.961 \\
\hline & & & & HYBRID & 198.1 & 45.7 & 1201.2 \\
\hline Langmuir & & & & Sips & & & \\
\hline$K_{\mathrm{L}}(\mathrm{L} / \mathrm{mg})$ & 10.25 & 21.42 & 37.53 & $q_{\mathrm{s}}(\mathrm{mg} / \mathrm{g})$ & 838.6 & 846.5 & 890.7 \\
\hline$a_{\mathrm{L}}$ & 0.019 & 0.043 & 0.073 & $a_{\mathrm{s}}(\mathrm{mg} / \mathrm{L})^{-1 / n}$ & 0.042 & 0.084 & 0.187 \\
\hline$q_{\mathrm{m}}(\mathrm{mg} / \mathrm{L})$ & 534.9 & 498.8 & 514.3 & $1 / s p$ & 0.592 & 0.490 & 0.336 \\
\hline$R^{2}$ & 0.929 & 0.907 & 0.900 & $R^{2}$ & 0.966 & 0.984 & 0.965 \\
\hline HYBRID & 986.1 & 548.7 & 2034.6 & HYBRID & 426.2 & 102.2 & 344.6 \\
\hline Dubinin-Radu & & & & Toth & & & \\
\hline$q_{\mathrm{s}}(\mathrm{mg} / \mathrm{g})$ & 530.8 & 538.3 & 545.0 & $q_{\mathrm{m}}(\mathrm{mg} / \mathrm{g})$ & 820.3 & 864.0 & 931.5 \\
\hline$E(\mathrm{~kJ} / \mathrm{mol})$ & 6.41 & 7.50 & 9.91 & $K_{\mathrm{To}}$ & 5.76 & 1.68 & 0.52 \\
\hline$R^{2}$ & 0.934 & 0.957 & 0.921 & tn & 0.502 & 0.353 & 0.217 \\
\hline HYBRID & 751.7 & 233.3 & 823.5 & $R^{2}$ & 0.957 & 0.975 & 0.946 \\
\hline & & & & HYBRID & 622.3 & 154.8 & 513.2 \\
\hline Temkin & & & & Khan & & & \\
\hline$K_{\mathrm{Te}}(\mathrm{L} / \mathrm{mg})$ & 0.62 & 0.73 & 14.00 & $q_{\mathrm{m}}(\mathrm{mg} / \mathrm{g})$ & 2.9 & 16.9 & 47.3 \\
\hline$b$ & 30.35 & 27.61 & 44.23 & $b_{K}$ & 823.7 & 214.6 & 164.3 \\
\hline$R^{2}$ & 0.896 & 0.964 & 0.919 & $a_{\mathrm{K}}$ & 0.587 & 0.691 & 0.775 \\
\hline HYBRID & 1252.0 & 210.2 & 652.3 & $R^{2}$ & 0.986 & 0.993 & 0.985 \\
\hline & & & & HYBRID & 170.6 & 32.5 & 150.6 \\
\hline
\end{tabular}


Table 5 Kinetic parameters for BB16 adsorption by montmorillonitic clay

\begin{tabular}{|c|c|c|c|c|c|c|c|c|c|}
\hline & \multicolumn{3}{|c|}{$250(\mathrm{mg} / \mathrm{L})$} & \multicolumn{3}{|c|}{$500(\mathrm{mg} / \mathrm{L})$} & \multicolumn{3}{|c|}{$1000(\mathrm{mg} / \mathrm{L})$} \\
\hline & $15^{\circ} \mathrm{C}$ & $25^{\circ} \mathrm{C}$ & $35^{\circ} \mathrm{C}$ & $15^{\circ} \mathrm{C}$ & $25^{\circ} \mathrm{C}$ & $35^{\circ} \mathrm{C}$ & $15^{\circ} \mathrm{C}$ & $25^{\circ} \mathrm{C}$ & $35^{\circ} \mathrm{C}$ \\
\hline \multicolumn{10}{|l|}{ Pseudo first-order } \\
\hline$q_{\mathrm{e}}(\mathrm{mg} / \mathrm{g})$ & 93.8 & 97.9 & 101.1 & 183.6 & 191.9 & 196.5 & 285.6 & 325.1 & 361.9 \\
\hline$k_{1}\left(\min ^{-1}\right)$ & 0.37 & 0.32 & 0.45 & 0.23 & 0.23 & 0.29 & 0.12 & 0.13 & 0.14 \\
\hline$R^{2}$ & 0.980 & 0.914 & 0.924 & 0.953 & 0.957 & 0.971 & 0.914 & 0.912 & 0.935 \\
\hline HYBRID & 4.0 & 8.5 & 10.5 & 80.3 & 12.0 & 2.6 & 90.9 & 122.4 & 87.9 \\
\hline \multicolumn{10}{|l|}{ Pseudo second order } \\
\hline$q_{\mathrm{e}}(\mathrm{mg} / \mathrm{g})$ & 100.9 & 101.8 & 104.0 & 203.5 & 203.8 & 205.3 & 338.1 & 373.9 & 409.1 \\
\hline$k_{2}\left(\times 10^{3}, \min ^{-1}\right)$ & 7.20 & 9.05 & 14.66 & 1.63 & 2.52 & 3.75 & 0.44 & 0.46 & 0.51 \\
\hline$h\left(k x q_{\mathrm{e}}^{2}, \mathrm{mg} / \mathrm{gmin}\right)$ & 73.2 & 93.8 & 158.7 & 67.3 & 104.6 & 158.0 & 50.0 & 64.8 & 85.5 \\
\hline$t_{1 / 2}(\min )$ & 1.4 & 1.1 & 0.7 & 3.0 & 1.9 & 1.3 & 6.8 & 5.8 & 4.8 \\
\hline$R^{2}$ & 0.989 & 0.986 & 0.986 & 0.993 & 0.989 & 0.995 & 0.957 & 0.961 & 0.978 \\
\hline HYBRID & 8.1 & 4.1 & 6.6 & 12.4 & 9.6 & 3.2 & 27.8 & 36.1 & 16.1 \\
\hline \multicolumn{10}{|l|}{ Weber-Morris } \\
\hline$k_{\mathrm{p}}\left(\mathrm{mg} /\left(\mathrm{g} \mathrm{min}^{1 / 2}\right)\right)$ & - & - & - & 5.99 & 1.15 & 2.25 & 20.67 & 25.27 & 20.74 \\
\hline$C$ & - & - & - & 152.1 & 185.7 & 183.3 & 154.7 & 167.5 & 233.9 \\
\hline$R^{2}$ & 0.994 & 0.991 & 0.993 & 0.998 & 0.994 & 0.997 & 0.996 & 0.999 & 0.999 \\
\hline HYBRID & 5.85 & 9.32 & 6.80 & 5.65 & 10.75 & 5.66 & 13.10 & 4.05 & 4.45 \\
\hline \multicolumn{10}{|l|}{ Vermeulen } \\
\hline$q_{\mathrm{e}}(\mathrm{mg} / \mathrm{g})$ & 94.1 & 98.3 & 101.3 & 191.7 & 193.6 & 197.4 & 304.6 & 346.7 & 378.1 \\
\hline$D_{\mathrm{i}}\left(10^{14} \mathrm{~m}^{2} / \mathrm{s}\right)$ & 4.51 & 3.76 & 5.55 & 1.78 & 2.58 & 3.38 & 0.97 & 1.02 & 1.25 \\
\hline$d_{\mathrm{p}}(\mu \mathrm{m})$ & 10.08 & 10.08 & 10.08 & 10.08 & 10.08 & 10.08 & 10.08 & 10.08 & 10.08 \\
\hline$R^{2}$ & 0.970 & 0.964 & 0.964 & 0.983 & 0.970 & 0.985 & 0.965 & 0.974 & 0.976 \\
\hline HYBRID & 3.6 & 7.4 & 10.6 & 11.7 & 7.1 & 1.8 & 21.9 & 39.1 & 22.0 \\
\hline
\end{tabular}

\subsection{Isotherm and kinetic modeling}

Experimental data and the predicted isotherms by nonlinear analysis for the adsorption of BB16 by montmorillonitic clay at $25^{\circ} \mathrm{C}$ is shown in Fig. 5. The calculated isotherm parameters, correlation coefficients and values of the Hybrid error function at all temperatures are given in Table 4. A comparison of models indicates that three-parameter models better describe the experimental data compared to twoparameter models. Similarly, other researchers obtained higher fits with three-parameter models for the adsorption of dyes (Vijayaraghavan et al. 2006; Kumar and Porkodi 2006), metal ions (Ho et al. 2002; Gunay et al. 2007), ammonium (Gunay 2007), and phosphate (Zeng et al. 2004).

Based on the $R^{2}$ and Hybrid values, Freundlich model had the highest correlation with experimental data compared to other isotherm models. At all temperatures studied, $1 / n$ values of Freundlich model and $\beta$ values of Redlich-Peterson model were less than one which indicates that adsorption of BB16 by montmorillonitic clay is favorable (Ozcan et al. 2007; Aksu and Kabasakal 2004). On the other hand, $1 / n$ values were closer to zero with the increases of temperature which suggest that montmorillonitic clay becomes more heterogeneous at elevated temperatures (Hameed et al. 2007). The heterogeneous characteristics of BB16 adsorption at higher temperatures is also supported by an decrease of th values of Toth model (Brdar et al. 2012). Higher favorability at elevated temperatures might be due to the increase in kinetic energy and the mobility of the dye molecules on the surface of the adsorbent (Netpradiat et al. 2004). The Redlich-Peterson isotherm model is a combination of Langmuir and Freundlich models and a higher correlation with experimental data indicate that the mechanism of BB16 adsorption was a hybrid process and does not follow ideal monolayer adsorption (Arami et al. 2008). The $q_{\mathrm{m}}$ values in the Langmuir equation indicate the monolayer capacity of montmorillonitic clay for BB16 adsorption and it decreases at higher temperature.

A comparison of four kinetic models for the adsorption of BB16 by montmorillonitic clay is given in Table 5 and Fig. 6. For all temperatures and concentrations considered here, $\mathrm{R}^{2}$ values obtained from all kinetic models are greater than 0.90, while Weber-Morris has the highest correlation and the lowest Hybrid values with the experimental data. The rate constant of pseudo-second-order model $\left(k_{2}\right)$ increased at 
elevated temperatures but decreased with the initial BB16 concentration. A similar relationship was reported for the adsorption of cationic dyes (Mahmoud et al. 2012; Gurses et al. 2006). On the other hand, the initial adsorption rate (h) increased with temperature and decreased with dye concentration except $500 \mathrm{mg} / \mathrm{L}$ at $25{ }^{\circ} \mathrm{C}$.

A determination of the rate-limiting step is an important factor for proper design of the adsorption process. WeberMorris model has been widely used to determine the rate control mechanism. Weber-Morris model suggests that the adsorption mechanism is controlled by intraparticle diffusion or more than two stages. When the plots do not pass through the origin, this is indicative of some degree of boundary layer control, and further showing that intraparticle diffusion is not the only rate controlling step, but also other processes may control the rate of adsorption. The slowest stage controls the overall rate of the adsorption process. Figure 7 presents the plots of $q_{t}$ versus $t^{0.5}$ for BB16 adsorption on montmorillonitic clay and distribution of data could be represented by three lines. Multi lines indicate that the adsorption rate of BB16 was controlled by three adsorption stages. The first line at the beginning of reaction represents the external mass transfer with a high adsorption rate. The second line indicates the intraparticle diffusion on rate control. The last line indicates the final equilibrium stage where intraparticle diffusion starts to slow down due to the extremely low BB16 concentration left in the aqueous solution (Wu et al. 2005; Vimonses et al. 2009). Similar results have been reported for dye adsorption (Toor and Jin 2012).

\subsection{Thermodynamic evaluation}

Thermodynamic parameters were calculated from Van't Hoff plots (Fig. 8). The calculated values of $\Delta H^{\circ}, \Delta S^{\circ}$, and $\Delta G^{\circ}$ for BB16 adsorption by montmorillonitic clay at different temperatures and initial dye concentrations are given

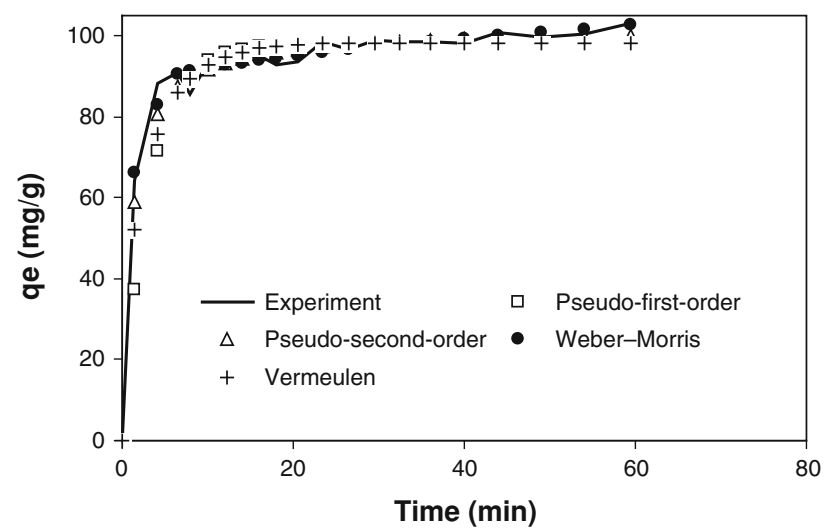

Fig. 6 Comparison of kinetic models $\left(\mathrm{T} 25{ }^{\circ} \mathrm{C}\right.$; initial dye concentration $250 \mathrm{mg} / \mathrm{L}$ ) in Table 6. At all conditions studied, all $\Delta G^{\circ}$ values were negative, indicating the spontaneous and feasible nature of BB16 adsorption by montmorillonitic clay. Adsorption of BB16 was more favorable at higher temperatures and lower initial dye concentrations due to higher negative values of $\Delta \mathrm{G}^{\circ}$. According to literature, $\Delta G^{\circ}$ values are between -20 and $0 \mathrm{~kJ} / \mathrm{mol}$ indicating that dye molecules are removed from the liquid medium by physical adsorption (Auta and Hameed 2012). The positive values of $\Delta S^{\circ}$ implied an increase in the degree of dispersion of the adsorbed species (Monash and Pugazhenthi 2009). The positive values of $\Delta H^{\circ}$ suggested that adsorption is an endothermic process and that heat is consumed during the adsorption of BB16 by montmorillonitic clay, which is also supported by an increase of adsorption capacity with temperature in Fig. 4. Similar thermodynamic results have been reported for dye adsorption by various clay minerals (Ozcan et al. 2005; Rodríguez et al. 2009; Xia et al. 2011).

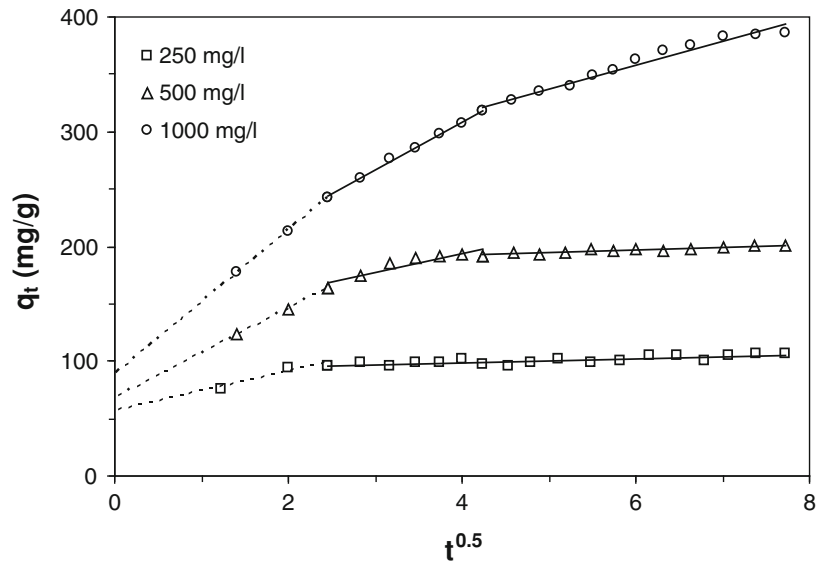

Fig. 7 Weber-Morris kinetic plots for BB16 adsorption by montmorillonitic clay

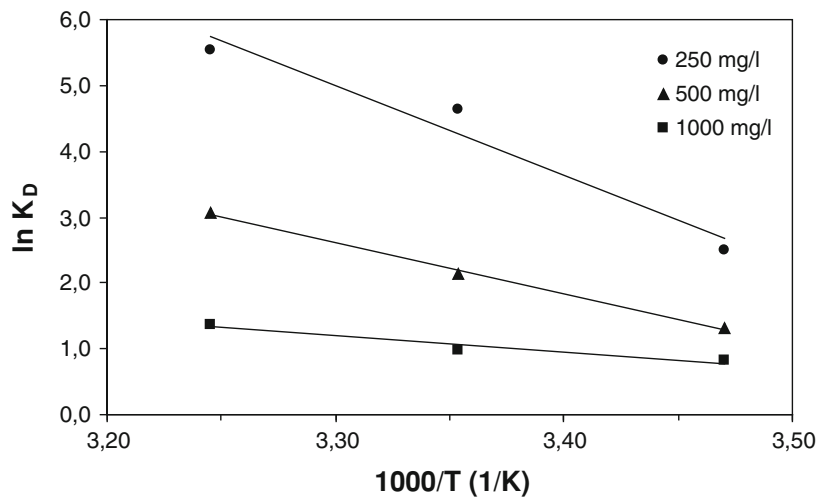

Fig. 8 Van't Hoff plots for the sorption of BB16 by montmorillonitic clay 
Table 6 Thermodynamic parameters for BB16 adsorption by montmorillonitic clay

\begin{tabular}{|c|c|c|c|c|c|}
\hline \multirow{2}{*}{$\begin{array}{l}C_{0} \\
(\mathrm{mg} / \mathrm{L})\end{array}$} & \multicolumn{3}{|c|}{$\Delta G^{\circ}(\mathrm{kJ} / \mathrm{mol})$} & \multirow{2}{*}{$\begin{array}{l}\Delta H^{\circ} \\
(\mathrm{kJ} / \mathrm{mol})\end{array}$} & \multirow{2}{*}{$\begin{array}{l}\Delta S^{\circ} \\
(\mathrm{J} / \mathrm{mol} \mathrm{K})\end{array}$} \\
\hline & $15^{\circ} \mathrm{C}$ & $25^{\circ} \mathrm{C}$ & $35^{\circ} \mathrm{C}$ & & \\
\hline 250 & -6.43 & -10.57 & -14.70 & 112.72 & 413.50 \\
\hline 500 & -3.09 & -5.43 & -7.76 & 64.21 & 233.57 \\
\hline 1,000 & -1.87 & -2.64 & -3.40 & 20.15 & 76.43 \\
\hline
\end{tabular}

\section{Conclusions}

The removal of BB16 by montmorillonitic clay was studied with respect to adsorbent dose, $\mathrm{pH}$, dye concentration and temperature. The removal of dye molecules from water is mainly due to hydrogen bonding and electrostatic interaction between BB16 molecules and clay. pH adjustment is not needed since the highest BB16 adsorption is at natural $\mathrm{pH}$ (3.6) of dye solution. The equilibrium time and amount of dye adsorbed increases with an increase of dye concentration. Temperature positively enhances the dye adsorption by increasing mobility of the dye molecules to the available surface of the adsorbent. Freundlich model best describes for the adsorption of BB16 onto the montmorillonitic clay, while Redlich-Peterson and Sips models also have a higher correlation with the experimental data. Isotherm parameters indicate that BB16 adsorption becomes more heterogeneous at higher temperatures. Weber-Morris model has the highest correlation when predicting the kinetic attitude of dye molecules and adsorption rate. Thermodynamic studies reveal that BB16 adsorption is spontaneous and endothermic nature, while a degree of dispersion increases with an increase in temperature. Experimental results show that montmorillonitic clay is a promising adsorbent for basic dye removal from aqueous solution.

Acknowledgments This research was financially supported by The Scientific and Technological Research Council of Turkey (TUBITAK) (Project Number: 109Y163).

\section{References}

Aharoni, C., Sparks, D.L.: Kinetics of soil chemical reactions: a theoretical treatment. In: Sparks, D.L., Suarez, D.L. (eds.) Rates of Soil Chemical Processes, pp. 1-18. Soil Science Society of America, Madison (1991)

Akbari, A.J.C., Aptel, P.: Treatment of textile dye effluent using a polyamide-based nanofiltration membrane. Chem. Eng. Process. 41(7), 601-609 (2002)

Aksu, Z., Kabasakal, E.: Batch adsorption of 2,4-dichlorophenoxyacetic acid (2,4-D) from aqueous solution by granular activated carbon. Sep. Purif. Technol. 35(3), 223-240 (2004)

Al-Degs, Y.S., El-Barghouthi, M.I., El-Sheikh, A.H., Walker, G.M.: Effect of solution $\mathrm{pH}$, ionic strength, and temperature on adsorption behavior of reactive dyes on activated carbon. Dyes Pigment. 77(1), 16-23 (2008)
Almeida, C.A.P., Debacher, N.A., Downs, A.J., Cottet, L., Mello, C.A.D.: Removal of methylene blue from colored effluents by adsorption on montmorillonite clay. J. Colloid Interface Sci. 332(1), 46-53 (2009)

Arami, M., Limaee, N.Y., Mahmoodi, N.M.: Evaluation of the adsorption kinetics and equilibrium for the potential removal of acid dyes using a biosorbent. Chem. Eng. J. 139(1), 2-10 (2008)

Auta, M., Hameed, B.H.: Modified mesoporous clay adsorbent for adsorption isotherm and kinetics of methylene blue. Chem. Eng. J. 198-199, 219-227 (2012)

Bergaya, F., Theng, B.K.G., Lagaly, G.: Handbook of Clay Science. Elsevier, Amsterdam (2006)

Bouafia-Chergui, S., Oturan, N., Khalaf, H., Oturan, M.A.: Parametric study on the effect of the ratios $\left[\mathrm{H}_{2} \mathrm{O}_{2}\right] /\left[\mathrm{Fe}^{3+}\right]$ and $\left[\mathrm{H}_{2} \mathrm{O}_{2}\right] /$ [substrate] on the photo-Fenton degradation of cationic azo dye Basic Blue 41. J. Environ. Sci. Health A. 45(5), 622-629 (2010)

Brdar, M., Sciban, M., Takaci, A., Dosenovic, T.: Comparison of two and three parameters adsorption isotherm for $\mathrm{Cr}(\mathrm{VI})$ onto Kraft lignin. Chem. Eng. J. 183, 108-111 (2012)

Bukallah, S.B., Rauf, M.A., AlAli, S.S.: Removal of methylene blue from aqueous solution by adsorption on sand. Dyes Pigment. 74(1), 85-87 (2007)

Chavez, M.L., Pablo, L., Garcia, T.A.: Adsorption of $\mathrm{Ba}^{2+}$ by Caexchange clinoptilolite tuff and montmorillonite clay. J. Hazard. Mater. 175(1-3), 216-223 (2010)

Chen, H., Zhao, J.: Adsorption study for removal of Congo red anionic dye using organo-attapulgite. Adsorption 15, 381-389 (2009)

Crini, G., Badot, P.M.: Application of chitosan, a natural aminopolysaccharide, for dye removal from aqueous solutions by adsorption processes using batch studies: a review of recent literature. Prog. Polym. Sci. 33(4), 399-447 (2008)

Demirbas, A.: Agricultural based activated carbons for the removal of dyes from aqueous solutions: a review. J. Hazard. Mater. 167(1-3), 1-9 (2009)

Dubinin, M.M.: The potential theory of adsorption of gases and vapors for adsorbents with energetically non-uniform surface. Chem. Rev. 60, 235-266 (1960)

Ely, A., Baudu, M., Basly, J.P., Ou, P., Kankou, S.O.: Copper and nitrophenol pollutants removal by Na-montmorillonite/alginate microcapsules. J. Hazard. Mater. 171(1-3), 405-409 (2009)

Eren, E., Afsin, B.: Investigation of a basic dye adsorption from aqueous solution onto raw and pre-treated bentonite surfaces. Dyes Pigment. 7681, 220-225 (2008)

Ersoy, B., Celik, M.S.: Effect of hydrocarbon chain length on adsorption of cationic surfactants onto clinoptilolite. Clays Clay Min. 51, 173-181 (2003)

Foo, K.Y., Hameed, B.H.: Insights into the modeling of adsorption isotherm systems. Chem. Eng. J. 156(1), 2-10 (2010)

Freundlich, H.M.F.: Über die adsorption in lösungen. Z. Phys. Chem. 57, 385-470 (1906)

Ghorbel-Abid, I., Jrad, A., Nahdi, K., Trabelsi-Ayadi, M.: Sorption of chromium (III) from aqueous solution using bentonitic clay. Desalination 246, 595-604 (2009)

Gimbert, F., Morin-Crini, N., Renault, F., Badot, P.M., Crin, G.: Adsorption isotherm models for dye removal by cationized starch-based material in a single component system: error analysis. J. Hazard. Mater. 157(1), 34-46 (2008)

Gok, O., Ozcan, A., Erdem, B., Ozcan, A.S.: Prediction of the kinetics, equilibrium and thermodynamic parameters of adsorption of copper(II) ions onto 8-hydroxy quinolone immobilized bentonite. Colloids Surf. A. 317, 174-185 (2008)

Gulnaz, O., Kaya, A., Matyar, F., Arikan, B.: Sorption of basic dyes from aqueous solution by activated sludge. J. Hazard. Mater. 108(3), 183-188 (2004)

Gunay, A., Arslankaya., E., Tosun, I.: Lead removal from aqueous solution by natural and pretreated clinoptilolite: adsorption 
equilibrium and kinetics. J. Hazard. Mater. 148(3), 708-713 (2007)

Gunay, A.: Application of nonlinear regression analysis for ammonium exchange by natural (Bigadiç) clinoptilolite. J. Hazard. Mater. 148(3), 708-771 (2007)

Gupta, V.K., Mohan, D., Sharma, S., Sharma, M.: Removal of basic dyes (Rhodamine B and Methylene Blue) from aqueous solutions using bagasse fly ash. Sep. Sci. Technol. 35(13), 2097-2113 (2000)

Gupta, V.K., Suhas.: Application of low-cost adsorbents for dye removal: a review. J. Environ. Manag. 90(8), 2313-2342 (2009)

Gurses, A., Dogar, C., Yalcın, M., Acıkyıldız, M., Bayrak, R., Karaca, S.: The adsorption kinetics of the cationic dye, methylene blue, onto clay. J. Hazard. Mater. 131(1-3), 217-228 (2006)

Hajjaji, M., Alami, A.: Influence of operating conditions on methylene blue uptake by a smectite rich clay fraction. Appl. Clay Sci. 44(1-2), 127-129 (2009)

Hameed, B.H., Ahmad, A.L., Latif, K.N.A.: Adsorption of basic dye (methylene blue) onto activated carbon prepared from rattan sawdust. Dyes Pigment. 75(1), 143-149 (2007)

Hameed, B.H.A.: Spent tea leaves: new non-conventional and lowcost adsorbent for removal of basic dye from aqueous solutions. J. Hazard. Mater. 161(2-3), 753-759 (2009)

Ho, Y.S., Mckay, G.: Pseudo-second order model for sorption processes. Process Biochem. 34, 451-465 (1999)

Ho, Y.S., Porte, J.F., McKay, G.: Equilibrium isotherm studies for the sorption of divalent metal ions onto Peat: copper, nickel and lead single component systems. Water Air Soil Pollut. 141(1-4), $1-33(2002)$

Ho, Y.S.: Second-order kinetic model for the sorption of cadmium onto tree fern: a comparison of linear and non-linear methods. Water Res. 40(1), 119-125 (2006)

Inbaraj, B.S., Chien, J.T., Ho, G.H., Yang, J., Chen, B.H.: Equilibrium and kinetic studies on sorption of basic dyes by a natural biopolymer poly $(\gamma$-glutamic acid). Biochem. Eng. J. 31(3), 204-215 (2006)

Iyim, T.B., Güclü, G.: Removal of basic dyes from aqueous solutions using natural clay. Desalination 249(3), 1377-1379 (2009)

Juang, R.S., Tseng, R.L., Wu, F.C.: Role of microporosity of activated carbons on their adsorption abilities for phenols and dyes. Adsorption 7, 65-72 (2001)

Karagozoglu, B., Tasdemir, M., Demirbas, E., Kobya, M.: The adsorption of basic dye (astrazon blue FGRL) from aqueous solutions onto sepiolite, fly ash and apricot shell activated carbon: kinetic and equilibrium studies. J. Hazard. Mater. 147, 297-306 (2007)

Khan, A.R., Al-Waheab, I.R., Al-Haddad, A.: A generalized equation for adsorption isotherms for multi-component organic pollutants in dilute aqueous solution. Environ. Tech. 17, 13-23 (1996)

Kumar, K.V., Porkodi, K.: Relation between some two- and threeparameter isotherm models for the sorption of methylene blue onto lemon peel. J. Hazard. Mater. 138(3), 633-635 (2006)

Langergen, S., Svenska, B.K.: Zur theorie der sogenannten adsorption geloester stoffe. Veteruskapsakad Handlingar 24(4), 1-39 (1898)

Langmuir, I.: The constitution and fundamental properties of solids and liquids, part I solids. J. Am. Chem. Soc. 38, 2221-2295 (1916)

Li, Y.H., Liu, T., Du, Q., Sun, J., Xia, Y., Wang, Z., Zhang, W., Wang, K., Zhu, H., Wu, D.: Adsorption of cationic red X-GRL from aqueous solutions by graphene: equilibrium, kinetics and thermodynamics study. Chem. Biochem. Eng. Q. 25(4), 483-491 (2011)

Lin, S.H., Teng, M.Y., Juang, R.S.: Adsorption of surfactants from water onto raw and $\mathrm{HCl}$-activated clays in fixed beds. Desalination 249(1), 116-122 (2009)

Lin, K.S., Cheng, H.W., Chen, W.R., Wu, C.F.: Synthesis, characterization, and adsorption kinetics of titania nanotubes for basic dye wastewater treatment. Adsorption 16, 47-56 (2010)
Liu, P., Zhang, L.: Adsorption of dyes from aqueous solutions or suspensions with clay nano-adsorbents. Sep. Purif. Technol. 58, 32-39 (2007)

Mahmoud, D.K., Salleh, M.A.M., Karim, W.A.W.A., Idris, A., Abidin, Z.Z.: Batch adsorption of basic dye using acid treated Kenaf fibre char: equilibrium, kinetic and thermodynamic studies. Chem. Eng. J. 181-182, 449-457 (2012)

Mane, M., Datta, M.: Adsorption characteristics of acid orange 10 from aqueous solutions onto montmorillonite clay. Adsorpt. Sci. Technol. 29(3), 301-318 (2011)

van der Marel, H.W., Beutelspacher, H.: Atlas of Infrared Spectroscopy of Clay Minerals and Their Admixtures. Elsevier Scientific, Amsterdam

Meshko, V., Markovska, L., Mincheva, M., Rodrigues, A.E.: Adsorption of basic dyes on granular activated carbon and natural zeolite. Water Res. 35(14), 3357-3366 (2001)

Monash, P., Pugazhenthi, G.: Adsorption of crystal violet dye from aqueous solution using mesoporous materials synthesized at room temperature. Adsorption 15, 390-405 (2009)

Netpradiat, S., Thiravetyan, P., Towprayoon, S.: Adsorption of three azo reactive dyes by metal hydroxide sludge: effect of temperature, $\mathrm{pH}$, and electrolytes. J. Colloid Interface Sci. 270(2), 255-261 (2004)

Ozcan, A.S., Ozcan, A.: Adsorption of acid dyes from aqueous solutions onto acid-activated bentonite. J. Colloid Interface Sci. 27, 639-646 (2004)

Ozcan, A.S., Tetik, S., Ozcan, A.: Adsorption of acid dyes from aqueous solutions onto sepiolite. Sep. Sci. Technol. 39, 301-320 (2005)

Ozcan, A., Omeroglu, C., Erdogan, Y., Ozcan, A.S.: Modification of bentonite with a cationic surfactant: an adsorption study of textile dye reactive blue 19. J. Hazard. Mater. 140(1-2), 73-179 (2007)

Ozdemir, E., Duranoglu, D., Beker, U., Avci, A.O.: Process optimization for $\mathrm{Cr}(\mathrm{VI})$ adsorption onto activated carbons by experimental design. Chem. Eng. J. 172(1), 207-218 (2011)

Porter, J.F., McKay, G., Choy, G.H.: The prediction of sorption from a binary mixture of acidic dyes using single- and mixed-isotherm variants of the ideal adsorbed solute theory. Chem. Eng. Sci. 54, 5863-5885 (1999)

Rauf, M.A., Iqbal, M.J., Ellahi, I., Hasany, S.M.: Kinetic and thermodynamic aspects of ytterbium adsorption on sand. Adsorpt. Sci. Technol. 13, 97-104 (1996)

Redlich, O., Peterson, D.L.: A useful adsorption isotherm. J. Phys. Chem. 63, 1024-1026 (1959)

Rodríguez, A., Garcia, J., Ovejero, G., Mestanza, M.: Adsorption of anionic and cationic dyes on activated carbon from aqueous solutions: equilibrium and kinetics. J. Hazard. Mater. 172(2-3), 1311-1320 (2009)

Roulia, M., Vassiliadis, A.A.: Interactions between C.I. Basic Blue 41 and aluminosilicate sorbents. J. Colloid Interface Sci. 291, 37-44 (2005)

Sakizci, M., Alver, B.E., Alver, O., Yorukogullari, E.: Spectroscopic and thermal studies of bentonites from Unye, Turkey. J. Mol. Struct. 969, 187-191 (2010)

Salleh, M.A.M., Mahmoud, D.K., Karim, W.A.W.A., Idris, A.: Cationic and anionic dye adsorption by agricultural solid wastes: a comprehensive review. Desalination 280(1-3), 1-13 (2011)

Sarioglu, M., Bali, U., Bisgin, T.: The removal of C.I. Basic Red 46 in a mixed methanogenic anaerobic culture. Dyes Pigments 74(1), 223-229 (2007)

Sevim, A.M., Hojiyev, R., Gul, A., Celik, M.S.: An investigation of the kinetics and thermodynamics of the adsorption of cationic cobalt porphyrazine onto sepiolite. Dyes Pigments 88, 25-38 (2011)

Sips, R.J.: On the structure of a catalyst surface. J. Chem. Phys. 16, 490-495 (1948) 
Tian, S., Jiang, P., Ning, P., Su, Y.: Enhanced adsorption removal of phosphate from water by mixed lanthanum/aluminum pillared montmorillonite. Chem. Eng. J. 151(1-3), 141-148 (2009)

Toor, M., Jin, B.: Adsorption characteristics, isotherm, kinetics, and diffusion of modified natural bentonite for removing diazo dye. Chem. Eng. J. 187, 79-88 (2012)

Toth, J.: State equation of the solid gas interface layer. Acta Chem. Acad. Hung. 69, 311-317 (1971)

Turabik, M.: Adsorption of basic dyes from single and binary component systems onto bentonite: simultaneous analysis of basic red 46 and basic yellow 28 by first order derivative spectrophotometric analysis method. J. Hazard. Mater. 158(1), 52-64 (2008)

Vermeulen, T.: Theory for irreversible and constant pattern solid diffusion. Ind. Eng. Chem. Res. 45(8), 1664-1670 (1953)

Vijayaraghavan, K., Padmesh, T.V.N., Palanivelu, K., Velan, M.: Biosorption of nickel(II) ions onto Sargassum wightii: application of two-parameter and three-parameter isotherm models. J. Hazard. Mater. 133(1-3), 304-308 (2006)
Vimonses, V., Lei, S., Jina, B., Chowd, C., Saints, C.: Kinetic study and equilibrium isotherm analysis of Congo Red adsorption by clay materials. Chem. Eng. J. 2(148), 354-364 (2009)

Wang, C.C., Juang, L.C., Hsu, T.C., Lee, C.K., Lee, J.F., Huang, F.C.: Adsorption of basic dyes onto montmorillonite. J. Colloid Interface Sci. 273, 80-86 (2004)

Wu, Z., Joo, H., Lee, K.: Kinetics and thermodynamics of the organic dye adsorption on the mesoporous hybrid xerogel. J. Chem. Eng. 112(1-3), 227-236 (2005)

Xia, C., Jing, Y., Jia, Y., Yue, D., Ma, J., Yin, X.: Adsorption properties of Congo red from aqueous solution on modified hectorite: kinetic and thermodynamic studies. Desalination 265, 81-87 (2011)

Zeng, L., Li, X., Liu, J.: Adsorptive removal of phosphate from aqueous solutions using iron oxide tailings. Water Res. 38(5), $1318-1326$ (2004) 